https://doi.org/10.31516/2410-5333.056.05

UDC 65.01(075.8)

V. Yu. Ilganayeva, lecturer, Uzhgorod Institute of Culture and Arts, Uzhgorod milian@ukr.net https://orcid.org/0000-0001-5588-362X

\title{
COMMUNICATION ASPECTS OF SOCIO-CULTURAL ENTREPRENEURSHIP AS A DEVELOPMENT SPHERE IN ECONOMY OF THE FUTURE ${ }^{1}$
}

The paper considers transformations in the economic subsystem of society under the influence of social-cultural factors in connection with information and media reality. Socio-cultural entrepreneurship in this context is a good object for analysis. The article defines several areas of the study of socio-cultural entrepreneurship: as a model of the future economy; as a subsystem of the economic sphere associated with culture and art; as a part of educational program contents. Socio-cultural entrepreneurship acquires the form of a social system with features of self-development, which clearly shows the importance of communication between all participants. Emphasis is placed on the need to include communication aspects in the study and analysis of economic relations.

Keywords: socio-cultural entrepreneurship, production, business, communication model, economic relationships.

В. Е. Ильганаева, преподаватель, коммунальное заведение высшего образования «Ужгородский институт культуры и искусств» Закарпатского областного совета, г. Ужгород

\section{КОММУНИКАЦИОННЫЕ АСПЕКТЫ СОЦИОКУЛЬТУРНОГО ПРЕДПРИНИМАТЕЛЬСТВА КАК СФЕРА РАЗВИТИЯ ЭКОНОМИКИ БУДУЩЕГО}

Рассматриваются преобразования в экономической подсистеме общества под влиянием социокультурных факторов в связи с информационной и медийной реальностью. Социокультурное предпринимательство в этом контексте является объектом анализа. Определены несколько направлений изучения социокультурного предпринимательства: как модель будущей экономики; как подсистема экономической сферы, связанная с культурой и искусством; как направление в образовательных программах. Социокультурное предпринимательство приобретает форму социальной системы с особенностями саморазвития, что наглядно демонстрирует важность общения между всеми участниками. Акцент делается на необходимость включения коммуникационных аспектов в изучение и анализ экономических отношений.

Ключевые слова: социокультурное предпринимательство, производство, бизнес, коммуникационная модель, экономические взаимоотношения.

1 This work is licensed under a Creative Commons Attribution-NonCommercialShareAlike 4.0 International License. 
В. Ю. Ільганаєва, викладач, комунальний заклад вищої освіти «Ужгородський інститут культури і мистецтв» Закарпатської обласної ради, м. Ужгород

\section{КОМУНІКАЦІЙНІ АСПЕКТИ СОЦІОКУЛЬТУРНОГО ПІДПРИЄМНИЦТВА ЯК СФЕРА РОЗВИТКУ ЕКОНОМІКИ МАЙБУТНЬОГО}

Актуальність. Актуальність розгляду комунікаційних складових соціокультурної діяльності, зокрема підприємницької, зумовлена новими умовами життя суспільства. що поширюються на всі сфери соціальної діяльності.

Мета статті. Встановити тенденції трансформації соціально-культурного підприємництва на новому етапі розвитку культури. Головним фактором змін вважається розвиток комунікації як інноваційної споживчої цінності у виробничих підприємницьких відносинах.

Методологія. Розгляд розвитку соціокультурного-підприємництва базується на основі використання соціокультурного підходу, завдяки чому вдалося пов'язати сучасний стан соціально-економічних феноменів з рівнем розвитку сучасної культури, де проявляються інтеграційні тенденції, що починаються з елементарних складових економіки, зокрема соціокультурного підприємництва.

Результати. Соціокультурне підприємництво набуває форми соціальної системи з особливостями саморозвитку, що наочно показує важливість спілкування між усіма учасниками. Водночас усі показники економічної діяльності залежать від якості взаємодії учасників сумісної дії. Медіапростір відіграє важливу роль у цьому процесі. Сфера культури та соціокультурна діяльність створюють нові умови для розвитку інновацій включаючи медіа-технології в процесах соціокультурного виробництва.

Новизна. Соціокультурне підприємництво набуває форми соціальної системи з особливостями саморозвитку, що наочно показує важливість спілкування між усіма учасниками. Визначається тенденція посилення комунікаційних зв'язків у сфері соціокультурного підприємництва як необхідного елементу майбутньої економіки. Модель виробничої комунікаційної взаємодії набуває форми «послуги для послуги» для досягнення спільного результату.

Практичне значення. Пропонується шлях практичної реалізації концепції соціокультурного підприємництва розглядати: 1 - як модель майбутньої економіки, 2 - як підсистему економічної сфери, пов'язаної з культурою та мистецтвом; 3 - як напрям підготовки фахівців для соціокультурної сфери. Висновки. Повернення до ремісництва можна розглядати як інноваційний напрям в організації виробничо-господарської діяльності, яка пов'язана 3 новими формами організації діяльності в медійному просторі, що пронизаний незліченними невидимими зв'язками. Це викликає жорстку залежність всіх виробників як матеріальних, так і духовних продуктів від якості комунікаційної взаємодії між ним. Нова економічна концепція соціокультурного підприємництва органічно вписується в тенденції, що описуються економічною наукою, а також відповідає оцінці ролі комунікаційної складової цієї діяльності.

Ключові слова: соціокультурне підприємництво, виробництво, бізнес, комунікаційна модель, економічні взаємовідносини. 
Problem statement. Some time has passed since the emergence of the metaphorical definition of the global society of modernity as a "global village" (M. McLuhan). According to researchers and theorists of the new form of socio-economic life of society, the metaphor "global village" will become quite real, because it corresponds to the evolutionary process of the economic forms. It was facilitated by the rapid development of communication technologies and the formation of a new social reality media space. The new living conditions of society extend to all spheres of social activity, including economy. So, the technical systems that ignore the human who in technocratic forecasts is subordinated to the global GOOGLE brain, is educated in GOOGLE class, and is included in the IT-structure, where each component of the production system complements the other in a single process to achieve one goal - to keep intact the existing system of connections and relations between people.

There is a need to consider the transformations in the economic subsystem of society under the influence of socio-cultural factors, the main of which is innovation and, as a consumer value, communication. The theoretical basis for this is well represented in the works of D. Bell, W.E. Deming, P. Drucker, P. Blenker, A. Melnik, A. Rogers, C. Spinoza, S. D. Sarasvathy, S. Venkataraman, N. Lumana, E. Toffler, M. Castells, and others.

The main text. Economy development models discussed by scientists and experts, one way or another, relate to the activities and communication relations in the production subsystem of society. Suffice it to mention the well-known economic development models by D Bell, S. McConnell, P. Drucker, W. E. Deming. In these and other works economists gradually abandon the traditional calculation of the material-labor component of profit and switch to the use of intangible elements of production. One such element is information, and more recently information has been supplemented by knowledge (Drucker, 2001).

We should also note that traditional approaches to the calculation of macro-economic indicators describing the well-being of countries and regions no longer meet the requirements not only related to the so-called objective well-being, but also don't meet the daily needs and prospects for improving the living conditions of people in the future (Jēkabsone\&Sloka, 2014). We can assume that this is, in fact, an approximation to the implementation of spiral models of the organization of social activities in the practical economy and management (Deming, 2018). At the initial stage of formation of the information society, the economy turned to the services industries, characterized by a significantly greater cost of human capital in comparison with material elements. The list of these industries includes education, innovation development, information-communication services, intellectual 
services, in particular consulting, information mediation, analytics, and marketing services. It is not by chance that the new is called information economy or knowledge-based economy (Bukovitz, 2002). Moreover, there is an increasing dependence of activities in some industries on the knowledge accumulated in other industries.

In business, in the context of the new economy, the very nature of competition between companies is changing, which already compete not only on the basis of material and financial resources, but on the basis of knowledge. Consumers are also changing. They purchase services and products for their own social and psychological actualization. The service sector, as the widest space of social interaction, is a segment of economic activity, which has a serious impact on the formation not only of tastes, scale and restrictive consumption trends, but also demonstrates new customer values. Services and products are purchased in accordance with the individual feeling of their own social identification and actualization of their values. The latter are now determined by the existing media space which opens some new opportunities for expressing individual creative ambitions.

Socio-cultural entrepreneurship has already been considered as an economic and cultural phenomenon. Several areas of research and application of cultural entrepreneurship theory in economy have been identified. It was shown that the Eastern European tradition is mainly characterized by the consideration of socio-cultural entrepreneurship in the context of socio-cultural activities and its relations with the economy, the processes of commercialization. At the same time, socio-cultural activities are related to the sphere of culture, including show business structures: night clubs, private cultural centers, private museums and so on. In addition, there is an opinion that the sphere of culture, socio-cultural activities is currently one of the least occupied business niches. It creates the basis to employees of sociocultural activity institutions to prepare more thoroughly for the development of innovation and entrepreneurship in this field. The researchers note that socio-cultural policy, socio-cultural actions, socio-cultural programs and so on occupy more and more living and economic space. Producers of creative products and services appeared on the market culture; new legal and ethical activities were formed (Economy of culture, 2006). The connection of all these aspects with the parallel development of each of them is characteristic of the Western European tradition (Castells, 1997; van Wering, 2003). However, the idea of socio-cultural entrepreneurship receives a deeper justification as a future model of the economy (Sarasvathy\&Venkataraman, 2011).

Socio-cultural entrepreneurship within the framework of the concept of socio-cultural activity is understood as a type of risky professional activity, 
which is, on the one hand, an initiative, independent activity of specialists and their associations aimed at achieving a better economic result, on the other - serves to meet the socio-cultural needs of the person and to solve social problems of our society (Economy of culture, 2006). Moreover, this definition is suitable for both economic and cultural aspects of the phenomenon.

The attractiveness of this sphere for investors and business consists in dynamic and mass character, breadth of application of creative qualities of managers and specialists, and fast circulation of capital. In addition, the sphere of cultural entrepreneurship makes it to establish trusting forms of relations with consumers. Entrepreneurship risks are determined rather by the imperfection of the legislation and poor preparation of those who are involved in the socio-cultural entrepreneurial process. The possibility of creativity, implementation of personal projects, expanding the scope of presentation of the results of activities or hobbies also attracts people. Socio-cultural entrepreneurship can also be described as an important social sphere that gives hope in situations of survival.

According to the available data, modern experience shows that various types of cultural and leisure activities around the world occupy a significant place in the economy and the organization of life of local communities, especially we take into account the emerging trend of decentralization of social management, especially in Europe. It should be noted that already at the initial stage of the study, several directions in research and practical implementation of the concept of socio-cultural entrepreneurship are distinguished: 1 - as a model of the future economy, 2 - as a subsystem of the economic sphere associated with culture and art; 3 - as a direction in educational programs. The third direction integrates the first two, presenting integrative training programs for the sphere of socio-cultural entrepreneurship.

Socio-cultural entrepreneurship takes the form of a social system with features of self-development, which clearly shows the importance of communication between all participants. At the same time, all economic performance indicators depend on the quality of interaction. Media space plays an important role in this process. The sphere of culture and sociocultural activity creates new places for the development of innovation and new technologies, including media technologies.

Similar interpretations of socio-cultural entrepreneurship shows the need for the convergence of different approaches to its study and confirm the importance of further study of the factors of strengthening the interaction of participants of socio-cultural activities in the context of the conditions of its implementation and organization. 
Actualization of communication aspects of social and cultural entrepreneurship is also caused by the fact that information production, which includes primarily those areas of creation of an intangible product: science, education, art, ideology in the broad sense of the word, as well as journalism, tourism, advertising, etc., are based on communicative forms of interaction of participants in the process. Countries that have taken key positions in this system are becoming leaders in the global division of labor. It is obvious that the main resource that ensures the functioning of these spheres is the human potential, primarily human intelligence, creative intelligence in particular.

Communicational interaction fills the sphere of economic, industrial and labor activities with new meanings and contents that meet the challenges of sustainable development of society. The main economic mechanism in the information and communication era is a universal exchange, which involves not only market relations, but also the convergence of participants' ideas about the quality of goods, production transparency, and the level of interaction with the consumer. The spread of innovative activity types corresponds to the growth of technical equipment of participants of sociocultural production and increase labor productivity as a response to the real demand of the market. The change of the economy structure in favor of services and socio-cultural entrepreneurship will occur at a rapid pace.

Conclusion. The possibilities of socio-cultural entrepreneurship are now virtually unlimited thanks to the latest communication technologies. In order to maintain and improve the sphere of social interaction, it is important to understand not only the structure of the social communication system, and properly establish social contacts, but also to be able to correlate the communication potential of production and business with the most important tasks of the functioning and development of social communities and society as a whole. It seems relevant and necessary to further study the main aspects of production and economic activity, the transformation of which is caused by changes in the nature of social activity and, above all, in its communication component. These aspects relate to the concept of economic development as a sphere of social and cultural entrepreneurship.

Therefore, returning to the beginning of this material, we note that returning to handicraft, can be considered as an innovative direction in the organization of production and business activities, which are tied to the new forms of organization of activities in the media space, permeated by countless invisible connections, causing a rigid dependence of all producers of both material and spiritual products. The new economic concept of socio-cultural entrepreneurship matches very well the trends described by 
economic science, and also corresponds to the assessment of the role of the communication component of activity.

Socio-cultural entrepreneurship is a manifestation of the service activities in which each serves the other and together they create the social product that they consume together. The evidential aspects of the consideration of socio-cultural entrepreneurship as a prototype of a new socio-economic structure of society and industrial activity require further research.

\section{References}

Drucker, P. (2001). Management Challenges for the 21st Century. Harper Business. [In English].

Deming, W. E. (1986). Out of the crisis. Cambridge: MIT Press. [In English]

Jēkabsone, I.; Sloka, B. Objective Evaluation of the Well-being of the Municipalities in Latvia. Socialiniai Tyrimai 2014, Issue 1, p. 42-52. [In English].

Stachera-Włodarczyk, S. (2019). Concept of Knowledge Management in Modern Enterprises. System Safety: Human - Technical Facility - Environment, 1(1), 987-995. [In English].

Economy of culture (2006) ed.. A.Y. Rubinstein, Moscow. [in Russian].

Castells, M. (1997) the Information Age: Economy, Society and Culture: The Power of Identity. Oxford: Blackwell Publ. [In English].

Van Wering, K. D. (2003) Economic meaning of culture and art. Management. Science. Education. Culture: Col. of scientific works. Saints-Petersburg. Saints-Petersburg University of Culture and Arts. [in Russian].

Sarasvathy, S. D., Venkataraman, S. (2011) Entreprenership as method: Open questions for an entrepreneurial future. Entrepreneurship Theory and Practice Vol. 35, №. 1, p. 113-135. [In English].

Надійшла до редколегії 25.11.2019 р. 